\title{
Preface: Matthean Perspectives
}

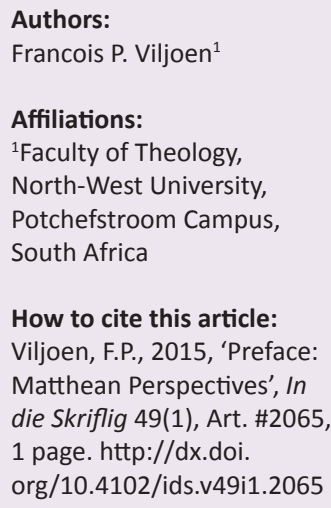

In recent years considerable scholarly work has been done on the first Gospel. The following examples, a few amongst many more, illustrate this fact. The 2009 Colloquium Biblicum Lovaniense was devoted to Matthean studies. The results of this conference were published in The Gospel of Matthew at the crossroads of early Christianity (2011), edited by Donald P. Senior. We are also fortunate to have extensive new commentaries on Matthew such as those by W.D. Davies and Dale C. Allison, Ulrich Luz, and Donald A. Hagner. The 1992-publication, What are the Gospels? by Richard A. Burridge on the genre of the gospels, has also enticed considerable interest in gospel studies.

To further stimulate this discussion on Matthew in South Africa, a conference was held at the Faculty of Theology of the North-West University in August 2014. Notable international and South African scholars participated in this conference during which 14 papers were read and thoroughly discussed. The conference provided an overview of the rich variety of scholarship on Matthew.

A selection of the above-mentioned 14 papers has been taken up in this volume of In Luce Verbi demonstrating some of the interesting intricacies of the first Gospel.

Francois P. Viljoen investigated the double love commandment in Matthew 22:34-40, considering the Mediterranean perspectives of group orientated societies prevalent in the 1st century. Reading the double love commandment from this perspective reveals remarkable aspects of the identity of the Matthean community.

Marius Nel investigated the possible denotations of the 'Sign of the Son of man in heaven' in Matthew 24:30. He explores two ways in which the phrase can be interpreted. Firstly, as the coming of the Son of man in the clouds, much like the lightning in Matthew 24:27, and secondly, in terms of various objects that will precede the coming of the Son of man.

Andries G. van Aarde provided a pragmatic-linguistic perspective on Matthew's portrayal of Jesus' disciples. He applies a pragmatic-linguistic reading strategy to Matthew 13:53-17:27, where the state of being of the disciples is described as 'little faith'. He argues that the integrity of the disciples' commission requires that they would overcome this fear.

Dale C. Allison shared some lessons he had learned from the history of the interpretation of Matthew. He demonstrates how careful Wirkungsgeschichte can help to identify noteworthy historical and exegetical proposals that were once in commentary tradition, but fell out for some reason. Allison provides several examples of these to illustrate this point. He proposes that such traditions should again be incorporated in the commentary tradition.

Bradley M. Trout presented an exegetical and theological study of the nature of the law's fulfilment in Matthew 5:17. He demonstrates something of the exegetical enigma of what precisely is meant by 'to fulfil the law and the prophets'. He argues that the biblical-theological theme of the Kingdom of God provides a measure of precision of what is meant by this text. Jesus fulfils the law and the prophets by inaugurating the Kingdom of God to which they pointed.

Marius J. Nel investigated the motive of forgiveness in Matthew. He illustrates the importance of the motif of forgiveness in this Gospel. He argues that the birth, life and death of Jesus as well as his words and deeds demonstrate Matthew's ethics of forgiveness. The confession that God has forgiven his people through Jesus, provides the main reason why they should forgive others.

Jos Verheyden explored the building blocks of Matthew. He evaluates J.A. Doole's thesis that Matthew predominantly used Mark and only made use of $\mathrm{Q}$ in a limited way - as long as it would not disrupt the dominancy of Mark. Opposite thereto, Verheyden demonstrates that Q played a more prominent role throughout Matthew than what Doole wants to acknowledge.

I would like to thank Jan G. van der Watt and Amanda L. du Plessis who assisted me in organising the Matthean Perspectives conference, and In Luce Verbi for publishing this volume. 